\title{
Development of Health Education Materials for Junior High School Students
}

\author{
$1^{\text {st }}$ Martin Sudarmono \\ Department of Health Physical Education and Recreation \\ Faculty of Sport Science, Universitas Negeri Semarang \\ Semarang, Indonesia \\ martinsudarmono_pjkrunnes@yahoo.co.id
}

\begin{abstract}
Teaching materials are very important in teaching and learning in schools. In Junior High School, the teaching materials used are not same with the curriculum, especially teaching materials of health education in physical education subject. The purpose of this research is to produce learning materials health education for junior high school students. This research is research development or $\mathbf{R} \& \mathbf{D}$ (Research and Developments). The research method used was the research of the development of health education materials in Junior high school in Semarang. Research data in the form of sheets of evaluation about the quality of the products and product improvement suggestions from Experts and teachers of physical education. Data analysis technique used is a descriptive analysis of the shape of the percentage. From this research obtained expert evaluation data amounted to $80.7 \%$ in health education and physical education teaching Experts of $\mathbf{7 9 . 5 \%}$, thus gained an average percentage of $80.125 \%$ and is included in the category of "good". While in field trials were obtained the following results: 1) physical education Teacher in SMP Negeri 31 Semarang of $88.63 \%, 2$ ) physical education Teacher in SMP Negeri 36 Semarang of $86.36 \%$, and 3) physical education Teacher in SMP Negeri 37 Semarang of $96.59 \%$, thus gained an average percentage of $90.41 \%$ and included in the category of "very good". The conclusion is the development of health education materials for junior high school students viable for use by learners in the learning of physical education in schools.
\end{abstract}

Keywords-development, health education material, student, junior high school introduction

\section{INTRODUCTION}

Health education is one of the materials taught in physical education subject starting from primary schools to secondary schools [5]. Learning resources basically teaching materials used in teaching and learning process which aims to facilitate the objectives and the learning process [3]. According to Setyosari [6] development in the sense of a common mean of growth, changes slowly (evolution), and changes gradually. Research and development commonly referred to with the development of research-based (research-based development).

According to Borg and Gall in the journal Ristya Astantry [7] research development is a process used to develop and validate product education. Furthermore mentioned that the development research procedure essentially consists of two main objectives, namely: to develop products and test the effectiveness of products to reach the goal.

While according to Gay in textbooks Wasis Dwiyogo [11] research and development is an attempt to develop a product that is an effective form of learning materials, media, learning strategies for use in school, not to test the theory. The resulting products in research and development, among others, training materials for teachers, learning materials for students, learning media to facilitate the learning, the learning system, and others.

Those definitions of the above, it can be concluded that the development in this research is the process of developing and testing the effectiveness of a product in the form of educational materials for use in schools in order to facilitate the process of teaching and learning so that learning goals can be achieved.

Learning materials are information, tools, and text that needed a teacher or instructor for planning and implementation study in learning. According Andi Prastowo [1] and also equipped by Pannen in 2001, materials are materials or subject matter are arranged systematically, which used the teachers and learners in the learning process. From other sources in the website dikmenjur.net retrieved more applicative sense that learning materials or materials teaching is a set of material or substance of learning (teaching material) that are arranged systematically, which shows the figure intact of competence which will be controlled by learners in the learning activities.

From a few opinions regarding understanding the learning materials, Andi Prastowo [1] stating the materials is any material (whether information, tools or text) that are arranged systematically, which shows the figure of the whole of the competencies will learner controlled and used in the learning process with the aim of planning and review of the implementation of learning. For example, modules, textbooks, handouts, or scale models, audio materials, interactive learning materials, and so on.

In the manufacture of materials needed for manufacturing materials, such materials are the lifeblood of learning. Need to realize that the learning resource is very important in putting together a learning materials. Therefore, the existence of a learning resource has at least three main objectives, namely to enrich the information required in compiling learning 
materials, can be used by the compiler of the materials, and makes it easy for learners to learn a certain competencies [1].

Have we known together that the materials are not the same as learning resources. For, materials have different types and shapes. However, the experts have made some categories for various materials. Some of the criteria to become a reference in the descriptions make the classification is based on its shape, how it works, and its nature, as outlined in the following explanation aka [1]: 1) Teaching materials according from shape, 2) Teaching materials according to how it works, 3) Learning materials by their nature

Rowntree in Andi Prastowo [1] says that by their very nature, learning materials can be differentiated into four different, as mentioned below.

Health education is a process of dynamic change in behavior, where the change is not simply the process of theory of matter or transfer from one person to another and neither set of procedures, but these changes occur due to consciousness from within the individual, group, or society itself [10]. While according to Rajendra K Erwin [2] health education is the process of helping someone, by acting in singly or collectively, to make decisions based on knowledge about the things that affect health her personal and others to increase the community's ability in maintaining his health and not just associate myself on improving knowledge, attitudes and practices, but also enhance or improve the environment (both physical or non physical) in order to maintain and improve the health of full consciousness. Sinta Fitriani [8] said that health education is a learning process which means that education occurs in the growth process, developments or changes toward more mature, better, more mature at the individual, group or the community. The health education is the process of behavior change healthy lifestyle based upon self awareness in individuals, groups or communities to maintain and improve health by applying the behavior patterns of healthy living. The process of changing student behavior at school one of them obtained from the process of learning in physical education sports and recreation.

Learning undertaken certainly has a goal, as well as health education. According to the Undang-undang Kesehatan No. 23 Tahun 1992 that the goal of health education, namely increasing the community's ability to maintain and improve the degree of health, either physical, mental and social so economically productive as well as social. Based on WHO the year 1954 in Sita Fitiriani [8] the goal of health education to change the behavior of people or society of unhealthy behavior or not healthy being a healthy behavior. You can conclude that the purpose of education is to teach people to know theirlilfe and apply a pattern of healthy living as a culture in everyday life.

The scope of health education can be seen from the various dimensions. The dimensions of the health education among other dimensions, the dimension of the education targets of the implementation and application and place the dimension level minions health (beautiful, 2013:143).

The problem in this research is how to model the development of health education materials for middle school students. This research aims to produce health education materials for the learning of physical education in junior high school.

\section{MATERIALS AND METHOD}

This research uses educational research and development, which is more familiar with the term Research \& Development ( R \& D). Understanding research development according to Borg \& Gall (1983) is a process used to develop and validate product education.

On the research of the development of this procedure, the development of health education materials made through several stages. These stages, among other things: 1) needs analysis by conducting literature review, observation and interviews, 2) sketch the initial product, 3) Validation expert, 4) revision of the initial Product, 5) field trials, 6) revisions to the final product, the final results of the form 7) development of health education materials for middle school students.

The following image is a draft product development health education materials for middle school students.

On the research of the development of these materials, the data retrieved is the quantitative data and qualitative data in the form of a reason in choosing answers and advice. The instruments used to collect the data researchers in his research is shaped instrument learning, the evaluation sheet and questionnaire.

\section{RESULT AND DISCUSSION}

Data obtained from filling the questionnaires by health education and physical education teaching is the expert guidelines for stating whether health education materials product deserves to be tested cobakan what does not. Following are the results of the questionnaire are charging from the experts:

TABLE 1. DESCRIPTION OF THE VALIDATION DATA EXPERTS

\begin{tabular}{|c|c|c|c|}
\hline No & Expert & Average score Assessment & $\%$ \\
\hline 1. & Health Materials & 3,23 & 80,7 \\
\hline 2. & $\begin{array}{c}\text { Learning Physical } \\
\text { Education }\end{array}$ & 3,18 & 79,5 \\
\hline \multicolumn{2}{|c|}{ Average } & 3,205 & 80,125 \\
\hline
\end{tabular}

Source: expert evaluation sheet

See a table of the results of the evaluation of the questionnaire done by charging each expert, then results obtained by filling the questionnaires as follows: 1) expert health education i.e. $80.7 \%$, belongs to the category of "good" 2) Expert teaching of physical education namely, $79.5 \%$, belongs to the category of "good". So come by the average percentage of $80.125 \%$ and is included in the category of "good". From the results of the data then it can be inferred that the media health learning materials using health education for junior high school students eligible for field trials.

Data obtained from the questionnaire by charging physical education Teachers SMP Negeri 31, SMP Negeri 36, dan SMP 
Negeri 37 in Semarang is guidelines for stating whether health education materials product deserves to be on the test used by the learners or not. Following are the results of the questionnaire are charging from teachers:

TABLE 2. THE RESULTS OF PHYSICAL EDUCATION TEACHER EVALUATION IN DATA DESCRIPTION

\begin{tabular}{|c|c|c|c|}
\hline No & $\begin{array}{c}\text { Physical } \\
\text { Education } \\
\text { Teachers }\end{array}$ & $\begin{array}{c}\text { Average score } \\
\text { Assessment }\end{array}$ & Persentase \\
\hline 1. & $\begin{array}{ll}\text { SMP Negeri } 31 \\
\text { Semarang }\end{array}$ & 3,54 & 88,63 \\
\hline 2. & $\begin{array}{ll}\text { SMP Negeri } 36 \\
\text { Semarang }\end{array}$ & 3,45 & 86,36 \\
\hline 3. & $\begin{array}{ll}\text { SMP Negeri } & 37 \\
\text { Semarang } & \\
\end{array}$ & 3,86 & 95,59 \\
\hline \multicolumn{2}{|r|}{ Avernge } & 3,61 & 90,41 \\
\hline
\end{tabular}

Source: teacher evaluation sheet

See a table of the results of the evaluation of the questionnaire done by charging each teacher, then results obtained by filling the questionnaires as follows: 1) Teachers of physical pendiidkan SMP Negeri 31 Semarang 88.63\%, belongs to the category "very good" 2) Physical Education Teacher in SMP Negeri 36 Semarang i.e. 86.36\%, belongs to the category "very good", and 3) Physical Education Teacher in SMP Negeri 37 Semarang i.e. $96.59 \%$, belongs to the category "very good". So come by the average percentage of $90.41 \%$ and included in the category of "very good". From the results of the data then it can be inferred that the media health learning materials using health education feasible for use by learners in middle school.

At this stage it's product revisions made after analyzing the results of the field trials. Product revision at this stage is conducted to find out the weaknesses and advantages of the products developed. For these materials the product refinement, the researchers added some parts that is the addition of a summary of the material and problems. Granting the summary it is expected that learners can better understand the fine points of existing material, while the addition of questions made to measure how much cognitive ability learners. Product revision at this stage produces the final product in the form of media development health learning materials using health education for junior high school.

\section{CONCLUSION}

Based on the results of analysis and discussion, then the conclusions that can be drawn from this study are as follows: 1) Based on the results of data analysis expert evaluation i.e. Expert health education gets a percentage of $80.7 \%$ and Expert teaching physical education gets a percentage of $79.5 \%$ so acquired average percentage of $80.125 \%$. Based on predetermined criteria then the media learning materials health education for middle school students this first meets the criteria that can be used for learners in school. And 2) Based on the results of the data analysis the evaluation of Teachers of physical education teacher i.e. SMP Negeri Semarang 31 gets a percentage of $88.63 \%$, teacher of physical education in SMP Negeri Semarang got 36 percentage of $86.36 \%$, and Physical Education Teacher in SMP Negeri 37 Semarang gets a percentage of $96.59 \%$ so acquired average percentage of $90.41 \%$. Based on predetermined criteria then the media learning materials health education for middle school students this first meets the criteria very well so it can be used for learners in school.

\section{REFERENCES}

[1] Andi Prastowo. 2015. Creative Guide Creating Innovative Instructional Materials. Yogyakarta: DIVA Press

[2] Erwin Setyo K. (2012). Concept, Process, and Application on Health Education. Yogyakarta: FIK UNY.

[3] Fahmi, dkk, 2017. Subject Materials Physical Education Sport and Health In Interactive Multimedia For Students Class VII. Journal of Physical Education and Sport Volume 2 Nomor 2. Februari 2017. Universitas Malang.

[4] Indah Prasetyawati Tri P.S. School Health Education As the Process of Changes in Student Behavior. Yogyakarta: FIK UNY

[5] Kurnia Eka Wijayanti, 2017. Research-Based Health Education Research: Reviews and Implementation in Indonesia. Journal of Physical Education and Sport Volume 9 Nomor 2. September 2017. UPI Bandung.

[6] Punaji Setyosari. 2010. Research Methods of Education and Development. Jakarta: Kencana

[7] Ristya Astantry. Development of LKS Teaching Materials In Teacher Learning Process For Class V Students at SD Islam Ta'allumul Huda Bumiayu Districts School Year 2012/2013. Semarang: FIK UNNES

[8] Sinta Fitriani. 2011. Health Promotion. Yogyakarta: Graha Ilmu

[9] Undang-Undang Kesehatan Nomor 23 Tahun 1992 about Health

[10] Wahid Iqbal M dan Nurul Chayatin. 2009. Public Health Science : Theory and Application. Jakarta: Salemba Medika

[11] Wasis Dwiyogo. 2004. Concept of Research and Development. Sports Policy Review Center LEMLIT UM 